\title{
Fijian social work practice
}

\section{Soro Ramacake}

Soro Ramacake is an indigenous Fijian who hails from Macuata, Vanua Levu in Fiji. He is a second generation New Zealand Fijian, who arrived in 1979. Soro works as a Social Worker in Schools for Ngapuhi Iwi Social Services. He has worked extensively with Pacific communities in Auckland, Wellington and Northland for many years. Soro has graduated with a Master of Social Work (Applied), Bachelor of Theology and is currently completing a Diploma in Counselling.

\begin{abstract}
This article considers part of a Massey Social Work Research Report from 2007, whereby a literature review on Fijian life principles, values, social standards and living was undertaken. Discussion was presented on the methodology employed for the research and key findings about Fijian values, knowledge, skills that form the basis for Fijian social work practice were highlighted. This article contributes to a growing body of literature on indigenous models.
\end{abstract}

\section{Introduction}

This article will present a selective literature review which provides in-depth information about ideal Fijian personality and Fijian social work practice. Next, it will introduce the veitalanoa ${ }^{1}$ methodology employed for this research. Then, it will highlight key findings from the interview with participants. Lastly, the article will provide a conclusion.

Fijian $^{2}$ society is tribal, made up of three confederacies (regional boundaries) Kubuna, Burebasaga and Tovata. A class system exists, consisting of multiple layered relationships through turaga (chief) and / or marama (lady) and the lewe-ni-vanua (commoners); the leweni-vanua operate in a systematised division of labour, where each person is born into a tribal role, having clear responsibilities.

Halapua (2003) asserts that the indigenous Fijian social framework is understood in terms that every aspect of life is interrelated. Fijian traditional value is steeped in collectivism, but modern Western values have exposed many Fijians to adopt individualism. Sienkiewicz (1999) claims that in the Fijian context individual activity is devoted to developing and reinforcing social relationships and promoting collective interests. Turaga (and marama), talatala (minister) and the mata-ni-vanua (literally meaning 'face for the people', in that regard, a spokesperson), play vital roles for maintaining unity, order, stability, reciprocity and hope of a tribe, and be it the community.

The act of having an informal chat or sharing of experiences and stories, where informality may be expected.

When Fijian is being used, it will mean the indigenous people of the land - itaukei is the new word adopted in Fiji. 


\section{Literature review}

Fijian traditional knowledge of caring and helping, although practised down through the ages, was rarely documented so written material on Fijian caring, social work, models and theories was limited. The little writing available came from literature which cover aspects of Fijian society and concepts of Fijian values. These include Scarr's (1952) The three legged stool, which highlights what Fijians consider important. These concepts are Vanua (land/people), Lotu (church) and Matanitu (nation). The Fiji Social Worker Journal of 2006, 2007 and 2008 is another literary contribution. The Four legged stool of Nainoca, Kurusiga, Vakacokaivalu, Waqairadovu \& Finau (2005), includes four essential values: $\mathrm{Na}$ Lotu (church), Nai Tavi (responsibility/obligation), Na Vuli (education/training) and $\mathrm{Na}$ Vuvale (the family).

Ravuvu (1983) argued that the ideal behaviour for Fijians is vakaturaga (to be of chiefly character), and I would add vakamarama (to be of lady-like character). Some of the vakaturaga characteristics (which can be said the same of vakamarama) are loloma (loving), veitaqomaki (protector), veivosoti (forgiving), vosota (patience), vakarokoroko (humble), vakarorogo (attentive listener), veidokai (respectful), veivukei (helper), veikauwaitaki (caring), veinanumi (considerate) and yalo malua (self-control).

The assertion by Mafile'o (2005) that Tongan social work practices are framed around relationships, rather than on a recognised professional position, is also true for Fijian. Sienkiewicz (1999) argues that in Fiji social action is guided by the tight affiliation of individuals with their communities. Fijian identity is grounded in one's connections to the immediate kinship group and social network.

Woods (1978) writes that before Christianity came to Fiji, Fijians showed themselves to be cheerful, intelligent, courteous and hospitable. When making reference to a letter written by Thomas Williams (missionary) in 1844 about a heathen chief, he states, 'he manifests great kindness to us'. With the advent of Christianity, Fijian cultural worldview was heavily influenced by principles such as love, kindness, gentleness, peace, goodness, self-control, patience, faithfulness, forgiveness, industriousness and humility. These principles permeated into families and village life and were reinforced by hymns, proverbs and by adults down through the age. Nainoca, et al. (2005) and Scarr (1952) placed great emphasis on lotu (church) playing a crucial and important role in social work.

Tora (1986), in his work on Fijian proverbs, refers to two important Fijian principles, one on industriousness: 'Na bogi ni cola qele' (this is the night for carrying soil) refers to the swamp crab having but one night to dig its hole and means, 'Life is short so keep busy'. The other is on humility, 'Dabe ena ibe qai kisi kina tabakau' (sit on the pandanus mat and on the coconut mat afterwards) means that 'if you take the high seat first you will be ashamed to have to move lower'.

Newport (2001) asserts that Pacific approaches to working with Pacific peoples are primarily determined by Western theoretical approaches. Baba, Mahina, Williams, \& Nabobo-Baba (2004) go on to highlight that Western paradigms fail Pacific people because they are fundamentally flawed, as they are so deeply embedded in colonisation that it has little potential for self-determination and development. Mafile'o (2005) highlighted that the development 
of indigenous social work theory must be rooted in Pacific values and language. Newport (2001) points out that knowledge is helped if it is constructed and validated by a cultural group that shapes their thinking and behaviour. Smith (Baba, et al., 2004) makes the comment that research in the Pacific must be obligated to the transformation of Pacific societies in accordance with Pacific values such as reciprocity and respect and aspirations.

Otsuko (2006) asserts that researchers should take time to establish a culturally-appropriate interpersonal relationship, and build a rapport with ethnic Fijian participants, prior to conducting the research. He went on to say that this can only be achieved through adhering to cultural protocols, for example, the presentation of a yaqona to clients prior to undertaking any work. A participant for this research commented that with any community work or project among Fijian, it is culturally wise to do a sevusevu to the key role player/s you engage with to get their approval and blessings and it also determines whether things will succeed or will fail. Nabobo-Baba (2006) supports this claim in saying,

The sevusevu is the yaqona presented by the visitor on arrival at the home, village or meeting one is entering or attending. The sevusevu is appropriate custom, and shows respect for the owners of the home, ceremony or function. Once the sevusevu is accepted, the purpose of the visit is readily embraced. It is advisable to check first whether people practise sevusevu, as some do not due to religious beliefs.

\section{Research methodology}

The research methodology utilised for this research was veitalanoa, which is similar to talanoa ${ }^{3}$. Talanoa has been used by people of the Pacific area in their research studies (Maka, Johansson-Fua \& Pene, 2006; Manu'atu, 2000). Capell (1991) asserts that talanoa is commonly practised by those who live in the Pacific Islands. Halapua (2005) argues that the way of the people of the Pacific nations is spoken rather than written. Vaioleti (2006) states that talanoa allows more real or authentic information to be available for Pacific research than data derived from other research methods. Burns (1990) confirms that: A face-to-face interaction assists in the establishment of rapport and higher level of motivation among respondents (Burns, 1990, p. 302). Otsuko (2006) stresses that a culturally appropriate methodology makes fieldwork more reliable and valued.

The data collection method used for the interviews was note-taking and data tape-recording.

\section{Recruitment method}

Fijian social workers from Fiji and New Zealand were highlighted as potential participants. Initially, the number of participants was going to be 10, but this proved difficult because it is not about whom you know but it was about being able to access the social and community workers given the low numbers of Fijian social workers available. In the end, seven participated. They were all Fijian practitioners in non-government agencies. Some work with Fijian families, others work with non-Fijian clients and/or families. Their line of work is either in the health or welfare sectors.

\footnotetext{
An informal chat or sharing of experiences and stories.
} 
It was difficult to take on more than seven participants due to the size of the project, timeframe, distance, workload and suggestion from the supervisor.

\section{Selecting the participants}

Purposeful sampling was employed for the purpose of this research, using a small number of participants (seven in all); three in Fiji and four in Northland, New Zealand. Participants were selected using the following criteria:

- Must be an indigenous Fijian.

- Must have some form of secondary or tertiary qualification.

- Must have more then two years' experience as a social worker and community worker.

- Must be over 25 years old.

To avoid conflict of interest, two intermediaries were used, one in Fiji and the other in Northland, New Zealand. For the purpose of this research, the intermediaries were selected by two close friends, who knew of potential participants that were suitable candidates for this research. Both intermediaries agreed to approach potential participants to get their approval in principle, to register their interest, and to provide their contact details for the researchers to make contact with them.

The intermediaries were given an information sheet which explained the research project to participants and a template for a follow-up letter. The intermediary in Fiji made the initial contact and provided names of three participants who were not known to the researcher. The Northland participants were chosen by another intermediary, and were known to me through my involvement with them in the Northland Fijian Group. The participants were sent a formal follow-up letter by emails or by post.

Other ethical issues included:

1. Safety issues, especially when the coup was happening. I did not know if I, as an overseas person, was allowed to conduct interviews with Fijian social workers.

2. Insider/outsider matters - whether a Fijian working outside Fiji would be welcomed and assisted.

3. Age issue - would a younger person, interviewing older workers be a barrier?

4. Gender issue - would being a male discourage female participants from participating fully and honestly?

5. Language barrier - would they understand the social work language being used?

6. Consent issue - consent was gained by the information and consent process being explained to the Fiji participants via email and for the Northland participants it was shared verbally, but oral consent would be gained on the day of the interview.

\section{Research questions}

Participants were asked the following six questions:

- What leads Fijian people to take on a social work role?

- What are the knowledge frameworks that you draw on in your practice?

- What are the skills you use in your practice? 
- How do Fijian values/principles influence your practice?

- What are the unique Fijian characteristics that you use in your practice?

- Are there any challenges / constraints in using Fijian values in your work?

Questions were asked in English and explained in Fijian, and responses could either be in English or Fijian.

\section{Key findings}

The summary of key findings is listed below:

1) What leads Fijian people to take on a social work role?

Participants were drawn to social work as a result of life experiences, coming from a dysfunctional family, had something to offer others, a sense of calling or duty, born to help, advice received and because of the qualities such as they possessed.

2) What are the knowledge frameworks that you draw on in your practice?

Traditional Fijian knowledge, Christian knowledge (post 1800s) and Western knowledge are major influences in their practice.

3) What are the skills you use in your practice?

The skills used in the practice were: openness to people, genuineness, self-awareness, humour, knowledge of cultural protocols and practices, thoroughness, rapport-building, trust-building, keeping calm, taking things slow and easy, patience, caring, sharing, having a loving tone, ability to relate to and get on well with all people, great communication skills, ability to hold a conversation, dedication, diligence, commitment.

4) How do Fijian values/principles influence your practice?

Fijian values that played an important part in practice included: veimaliwai vinaka (relating well to people), and kila nai tovo vakavanua (knowledge of Fijian cultural protocol). For example, a participant added:

Prior to doing any work with a Fijian family or community, I normally do the culturally appropriate thing, by going to see the mata-ni-vanua or appropriate person in the family or community to gain access into the community or lives of those they would like to see.

The values of loloma (loving), veikauwaitaki (caring/hospitable), veinanumi (consideration), veiwasei (sharing) and veivukei (helper) are evidenced in Fiji by the practice of calling out to people (that you may know or total strangers) who may pass your home to 'lako mai, mai kana' (come in to eat). Other values include vakarokoroko (humility), vakarorogo (attentive listener), dau cakacaka (industriousness), dina nomu cakacaka (having a good work ethic), vakarokoroko (humility), veidokai (respect), veivosoti (forgiving), veiciqomi (acceptance), veitokoni (supportive), vosota (patient), and veiwali (humour). Christian principles were also used in social work practice.

5) What are the unique Fijian characteristics that you use in your practice?

The unique Fijian characteristics used in practice were helping, hospitality, doing things together as a community, to share and care for one another, even to total strangers. 
6) Are there any challenges/constraints in using Fijian values in your work?

Fijian values still shaped, motivated and drove the practice for New Zealand Fijian workers and had certainly become more relevant and effective in a Western world. It is about balancing the two worlds for the betterment of those that they serve.

\section{Conclusion}

In conclusion, Fijian community and social work are influenced by traditional Fijian knowledge, Christian knowledge and Western knowledge. Key ideas and values that are seen as important are vakaturaga, vanua, church, nation, family, responsibility, education, industriousness, relating well to people, knowledge of Fijian cultural protocol and use of Christian principles. Veitalanoa methodological approach is a relevant and worthwhile tool in conducting social work research among Fijian.

\section{References}

Baba, T., Mahina, O., Williams, N., \& Nabobo-Baba, U. (2004). Researching the Pacific and indigenous peoples: Issues and perspectives. Auckland: Centre for Pacific Studies.

Burns, R. B. (1990). Introduction to research methods (4th ed.). NSW, Frenchs Forest: Pearson Education.

Capell, A. (1991). A new Fijian dictionary. Suva: Government Printer.

Halapua, W. (2003). Tradition, lotu \& militarism in Fiji. Lautoka: Fiji Institute of Applied Studies.

Halapua, S. (2005). Talanoa: Talking from the heart. Matangitonga. Retrieved from http: / / www.matangitonga.to/article/features/interviews / DrSitiveniHalapua221205.shtml

Healy, K. (2005). Social work theories in context: Creating frameworks for practice. Houndmills: Palgrave Macmillan.

Kay, R. (2006). Yaqona (kava) drinking. Retrieved, June, 23, 2007, from http://www.fijiguide.com/Facts/kava. html $\backslash$

Mafile'o, T. (2005). Tongan metaphors of social work practice: Hange ha pa kuo Fa'u. Unpublished PhD Thesis, Massey Universty.

Maka, L., Johansson-Fua, S., \& Pene, F. (2006). Ta kupesi: Emerging themes and methodologies from educational research in Tonga. IOE/USP.

Nabobo-Baba, U. (2006). Knowing and learning an indigenous Fijian approach. Retrieved from http:/ / books.google. co.nz/books?

Nabobo-Baba, U. (2004). Research and Pacific indigenous peoples: Silenced pasts and challenged futures. In T. L. Baba, O. Mahina, N. Williams \& U. Nabobo-Baba (Eds.), Researching Pacific and indigenous peoples: Issues and perspectives (pp. 17-32). Auckland: Centre for Pacific Studies, University of Auckland.

Nainoca, M. G., Kurusiga, A., Vakacokaivalu, E., Waqairadovu, J., \& Finau, M. (2005). Nai dabedabe: A model of practice for social work in Fiji. The Fiji Social Workers Journal, 1(1), 8-12.

Newport, C. (2001). Knowing practice Pasifika. Social Work Review/Tu Mau, 13(3), 6-9.

Newport, C. (2003). Pacific evaluation: Values, voices and methodological considerations. In N. Lunt, C. Davidson and K. McKegg (Eds.). Evaluating policy and practice. New Zealand: Pearson Education NZ, pp.151-156.

Otsuko, S. (2006). Talanoa research: Culturally appropriate research design in Fiji. Paper presented at the Proceedings of the Australian Association for Research in Education (AARE) 2005 International Education Research Conference., Melbourne, Australia.

Ravuvu, A. (1983). Vaka I Taukei - The Fijian way of life. Suva: The Institute of Pacific Studies of the University of the South Pacific.

Scarr, D. (1952). Fiji: The three-legged stool. Selected writings of Ratu Sir Lala Sukuna. New Zealand Journal of History, 19(2).

Sienkiewicz, S. (1999). Ethnic relations in Fiji: Peaceful coexistence and the recent shift in the ethnic balance. Retrieved, May, 9, 2007, from http: / / cdc.union.edu/PUBLIC/ ANTDEPT / fiji99/sienkiewicz/ssind6.htm

Talanoa Excerpts (2001). Talanoa I. Retrieved 18 January 2011, from http://aut.researchgateway.ac.nz/bitstream/10292/919/1/LatuM.pdf Tora, V. (1986). Yaqona in Fiji. In Pacific rituals - living or dying (pp. 25-35). Suva: University of the South Pacific.

Vaioleti T. M. (August, 2003). Talanoa research methodology: A developing position on Pacific research. Paper presented at the Pacific Research: Education Symposium, University of Waikato, NZ.

Vaioleti, T. M. (2006). Talanoa research methodology: A developing position on Pacific research. Waikato Journal of Education 12(15).

Woods, H. A. (1978). Overseas missions of the Australian methodist church (Vol. II). Victoria: The Dominion Press. 